\title{
FOREIGN LANGUAGE EDUCATION AS A PHILOSOPHICAL, SOCIAL, PSYCHOLOGICAL AND PEDAGOGICAL CATEGORY
}

\author{
Irina Onishchuk \\ ORCID iD 0000-0003-3690-9681 \\ Post Graduate Student \\ Vinnytsia State Pedagogical University named after Mykhailo Kotsiubynsky \\ 32 Ostrozhsky Str., 21100 Vinnytsia, Ukraine \\ irinaon21@gmail.com
}

\begin{abstract}
Foreign language education is one of the priority areas of Ukraine's educational policy. It exists not only for teaching students to acquire a foreign language, but also aims to enrich the inner world of a person, to make it more erudite, bring society to a new level. One of the strategic directions in modernizing of education is the overcoming of reproductive mass education and the transition to a new educational paradigm, which provides cognitive activity and autonomy of thinking of those who study. "The school should teach how to think and teach how to study» - these are the pedagogical imperatives of the modern era.
\end{abstract}

Key words: category; cognitive-psychological space; educational paradigm; foreign language education; foreign language; modeling of the speech activity project.

\section{INTRODUCTION AND ANALYSIS OF PREVIOUS RESEARCH}

Foreign language education is considered as a social, philosophical and psychological and pedagogical category that proves its scale and versatility. Foreign language education is one of the priority areas of Ukrainian educational policy, for which today foreign language teaching systems are being established at educational institutions on the basis of common documents, directives and recommendations developed by the institutions of education and language policy of the Council of Europe.

In the writings of Ukrainian scientists, various aspects of the problem of foreign education were actualized: the peculiarities of its development and functioning in the context of modern approaches to teaching foreign languages in European countries (G. Grinyuk, S. Nikolaeva, O. Misechko); Social and cultural components of the content of teaching a foreign language in the context of European education (O. Maksimenko, O. Pershukova,); comparative analysis of trends in the management of basic education in modern European countries (L. Grinevich, A. Sbrueva); linguistic principles of the problems of formation of foreign language competence of pupils and students (V. Plahotnik, V. Redko, etc.).

The purpose of the article is to consider foreign language education as a philosophical, social, psychological and pedagogical category. 


\section{THE MAIN MATERIAL}

Let's consider the notion "education". Wikipedia defines this concept as a process that promotes knowledge, or the acquisition of knowledge, skills, values and believes. In the "Great Dictionary of Contemporary Ukrainian Language", education is defined as "a set of knowledge that is gained in the process of learning, a system of educational activities" (Busel, 1728, p. 857). In both definitions we consider the presence of not only knowledge, skills and abilities, but also values, believes, systems of educational measures, which indicates the extraordinary complexity of the tasks of educators. It is noted that, first and foremost, it is an applied linguistics branch, although it can also be considered as an interdisciplinary branch, as in foreign language education there are four main areas: communicative competence, abilities and intercultural experience.

Goals, content, educational technologies, resource base of teaching of foreign languages are updated. In the teaching of foreign languages the latest world achievements are actively borrowed. National scholars and public figures defend the idea that the studying of the languages of European nations will raise awareness of the belonging of our people to European civilization and will allow young generation to conduct a parity dialogue with Europeans, to get acquainted with the civilizational values of the European space (Nikonova, 1969, p. 87-91).

An authoritative philologist G. Kryuchkov (2002) explicitly describes the current strategy of foreign languages teaching in Ukraine. "An individual, who speaks only one language, is in limited intellectual, mental, cognitive and psychological spaces. Learning at least one foreign language removes certain restrictions, and this space is doubled. With the learning of the third language a person achieves some diversity, through which the communicants open the way to knowledge, perception, understanding and self-improvement" (p. 12).

Knowledge of the essence of mental processes that accompany any educational process, in particular foreign language communication, will help the teacher to create the appropriate pedagogical conditions and to provide the effectiveness of the whole educational process.

Psychologists perceive a special kind of activity aimed at meeting communicative needs in speech. Speech, like any other activity, is characterized by two opposite sides: external and internal ones. The inner side (thinking, ordering of thoughts, searching for necessary, "close" words or phrases) regulates the external one. In the speech, such an inner side is the process of expressing the content (Zhinkin, 1982, p. 65). The external side is called an executive side, it is expressed by articulation. It should be noted that the external process of broadcasting is not just a vocalization of internal broadcasting, but primarily its reconstruction and improvement.

So, speech as activity is characterized by the unity of the two above-mentioned parts. "It begins with the motive and plan and ends with the result, with the achievement of the goal; in the middle there is the dynamic system of concrete actions and operations aimed at achieving this result" (Leontiev, 1969, p. 26).

The goals of the various vocational-oriented foreign languages correspond to the common goal of the educational process in the multi-disciplinary institution of higher education, namely, the professional training of a future specialist in labor functions. The development of the secondary linguistic personality of a future specialist is realized through the development of communicative-cognitive and 
social qualities, the formation of a language-speaking communicative competence as a characteristic of the linguistic personality at different levels of higher education, the formation of skills of independent work in mastering a foreign language for professional purposes. The content of education is a holistic «picture of the world of a secondary linguistic person operating in a professional context», which gives the freedom to choose a personally significant option; flexibility and mobility of knowledge; differentiation of content (Timkina, 2007).

Let's consider the sequence of teaching foreign language broadcasting from the standpoint of psychology. The need makes the role of "triggering mechanism", "energy source" of speech activity. However, it may remain unrealized in the absence of appropriate conditions. And only when there is a combination of actual needs (in our case, communicative) with conditions that are able to satisfy it (such conditions in the case of learning foreign languages is the presence of a speech situation), in the human body there is a certain dynamic state, which is expressed in the psychological readiness to show behavior in the appropriate direction. Such readiness for activity is called "prescription". Thus, the initial mechanism is the commissioning of motivation.

One of the most important points of foreign languages education are the specific needs for a foreign language broadcasting. Analyzing the motivational sphere of university students, the researchers came to the conclusion that particular importance for the effectiveness of educational activities is to update such needs: cognitive, communicative, creative, as well as the need for achievement of the goal. The communicative need is unanimously recognized by psychologists as one of the main sociogenic needs of a man. It is the most significant in the teaching of oral speech, in the student's motivation field it occupies one of the leading places. According to O. Leontiev, the creation of the best conditions for the development of the motivation and creative nature of educational activities is possible in the process of communication. Accordingly, the process of learning foreign languages is advisable to build as a model of the process of communication. "It is necessary to teach the activity itself, through the mastering the means and methods of which the one who learns will be also formed" (Zhinkin, 1982, p. 73).

External motives include orientation on self-affirmation, prestige, duty, necessity, avoidance of troubles, etc. The internal motives are formed within the process itself and, of course, it is better if they prevail. Otherwise, the motivation that led the person to the learning process may be too weak to keep him in this situation, and may eventually lead to a person's refusal of continuance. The predominance of internal or external motivation much depends on the teacher, on his ability to create a problem and to make the topic personally significant, on the emotionality and self-interest of the teacher himself in the subject of his teaching. Then the motivation will be high, students will see a specific goal and they will do their best to achieve it. A certain purpose is an impetus for reflection or thinking; as a result there are thoughts and ideas. L. S. Vyhotskyi very closely compared the thoughts with a hanging cloud, from which it is about to rain the words, and motivation with the wind that drives these clouds. The subject of thinking is very relevant today, because the development of thinking is an important prerequisite for self-development and self-improvement. As follows, the command of the language is in unwavering unity and direct connection with thinking (Kovalenko, 2005, p. 13).

So, as we see, oral speech is a complex psychological process. Therefore, when teaching, it is necessary to pay due attention to the important components of 
this system, primarily the development of thinking, which plays a particularly important role in mastering communication. It is necessary to train and students' ability to decode the received information, and to store it in memory. However, it is necessary to take into account not only the psychological features of the speech process, but also the psychological characteristics of students as individuals, because psychology is a science of the subject, which should be influenced by every teacher (Borisenkov, 2004, p. 103).

Interest in the language, its origin and characteristics, and other languagerelated issues go beyond the scope of linguistics and can be said to be one of the most important philosophical problems.

Later, in the Middle Ages, much attention was paid to the correlation of words and concepts that shifted the emphasis from the word to the sentence, the subject of which was considered to have certain properties and participates in the relationship. In the context of philosophy, discourse is not limited to the analysis of individual sentences, but also texts that are composed of sentences that do not contradict each other.

The development of the philosophy of the sentence contributed to the fact that philologists, philosophers, logics, psychologists began to focus their efforts on the study of the theory of meaning and the laws of syntax, since the strategic goal of the sentence philosophy was to achieve maximum clarity in the understanding of language.

The modern age is characterized by considering the language in terms of philosophy value orientations: the language is created and used by people not arbitrarily, but according to their purposeful activity, practice, while the person is interested not only in truth (as in the philosophy of the sentence), which shows the object as it is irrelevant to the goals of man, and value of an object for a person (Devitt, 1999, p. 260-283).

L. Weissgerber believed that the force is laid in the language, "energy", which much affects its consciousness in all spheres of spiritual culture, including in the field of science, although he did not identify the scientific and linguistic picture of the world, in contrast to E. Cascier, who recognized the power of speech over scientific consciousness at the initial stage of the activity of a scientist, aimed at studying a particular subject. He wrote: “... the starting point of any theoretical knowledge is already formed in the language world: both the naturalist, and the historian, and even the philosopher sees the objects first as they are given them with the help of the language" (Radchenko, 2006, p. 116).

E. Kassierer believed that the scientist should strive to overcome the power of speech over his research consciousness: “... scientific knowledge, grown up in language concepts, can not but seek to leave them, because it calls for the necessity and universality of the language as the carriers of certain diverse worldviews can't be answered" (Radchenko, 2006, p. 117).

Consequently, we can conclude that foreign-language education is an integral part of the learning process. And it is considered not only as a philological term, but also as a philosophical, social, psychological and pedagogical category.

\section{REFERENCES}

Borisenkov, V. P. (2004). Challenges of the Modern Era and Priority Tasks of Pedagogical Science. Pedagogics, 1, 3-10. 
Busel, V. T. (1728). Great explanatory dictionary of contemporary Ukrainian language (with additional and additional materials). Kyiv - Irpen, Ukraine: VTF "Perun".

Zhinkin, N. I. (1982). Speech as a guide for information. Moscow, Russia: Nauka.

Kovalenko, O. (2005). On the Way to the Democratization of Society - Foreign Languages in Educational Institutions. 3, 92-100.

Kryuchkov, G. (2002). Strategy of teaching foreign languages in Ukraine, 1-2, 10-13.

Leontiev, A. A. (1969). Language, speech, speech activity. Moscow, Russia: Enlightenment.

Nikonova, S. M. (1969). The origins of the Soviet method of teaching foreign languages. Moscow, Russia: Higher school.

Passov, E. I. (2008). "Tank of modernization" in the field of education. Moscow, Russia: GLOSSARY-PRESS.

Radchenko, O. A. (2006). Language as worldview. Linguophilosophical concept of Neogumboldtianism. Moscow, Russia: KomKniga.

Timkina, Yu. Yu. (2007). Advantages and problems of variative innovative education in the high school International Research. DN Hippopotamus Journal, 04 (58). doi: 10.23670/IRJ.2017.58.025

Devitt, M. (1999). Language and Reality: An Introduction to the Philosophy of Language. A Bradford Book. 